Article

\title{
Yeasts from Different Habitats and Their Potential as Biocontrol Agents
}

\author{
Julia Pretscher, Tilman Fischkal, Sina Branscheidt, Lucas Jäger ${ }^{\circledR}$, Susann Kahl, \\ Martina Schlander, Eckhard Thines and Harald Claus * \\ Johannes Gutenberg-University Mainz, Institute for Molecular Physiology, Microbiology and Wine Research, \\ Becherweg 15, 55120 Mainz, Germany; julia.pretscher@online.de (J.P.); tilman.fischkal@yahoo.com (T.F.); \\ ibransch@students.uni-mainz.de (S.B.); ljaege02@students.uni-mainz.de (L.J.); \\ sukahl@students.uni-mainz.de (S.K.); schlande@uni-mainz.de (M.S.); thines@uni-mainz.de (E.T.) \\ * Correspondence: hclaus@uni-mainz.de; Tel.: +49-6131-392-3542
}

Received: 14 March 2018; Accepted: 19 April 2018; Published: 24 April 2018

\begin{abstract}
Ever since plant diseases began causing losses in viticulture, the control of phytopathogenic fungi has become of vital interest for winemakers. The occurrence of novel pests, fungicide resistance, and changed consumer expectations have led to an enormous demand for novel plant protection strategies. As part of integrated protection measures, antagonistic microorganisms have been investigated to a large extent. Such microorganisms can be applied not only in conventional, but also in organic farming as biological control agents (BCA). Particularly, yeasts were found to be interesting candidates for the development of BCA. Many of these eukaryotic microorganisms are found as part of the phylloplane microflora. In this study, we assessed a set of 38 yeast isolates from different habitats, including the guts of termites, for inhibitory effects against some phytopathogenic fungi that have received less attention in earlier studies. The majority of yeasts were found to interfere with fungi infecting grapevine (Eutypa lata, Botrytis cinerea, and Roesleria subterranea), stone fruits (Monilinia fructicola), or rice (Magnaporte oryzae), as well in vitro and in model experiment on fruits. Although most yeast strains secreted glycoside hydrolases and proteases, attempts to demonstrate direct antagonistic activities of lytic enzymes failed. However, in culture filtrates of the termite yeast Papiliotrema odontotermitis OO5, a low molecular thermostable antagonistic factor was detected. Iron depletion as a BCA mechanism was confirmed for strains of Metschnikowia pulcherrima but not for other yeasts.
\end{abstract}

Keywords: biological control agents; yeasts; phytopathogenic fungi; competition; lytic enzymes; pulcherrimin; termite

\section{Introduction}

Pathogenic fungi cause significant annual losses in the quality and quantity of crops, resulting in considerable economic damage. Furthermore, fungi are profound producers of secondary metabolites that are toxic to humans when consumed [1]. Botrytis cinerea (teleomorphic form: Botryotinia fuckeliana) has been identified as pathogen of more than 235 plant species, including grapes, lettuce, tomatoes, tobacco, and strawberries [2]. In viticulture, B. cinerea may cause serious loss (gray rot) but also improvement of wine quality (noble rot), depending on the stage of ripening in which the berries are infected and on the weather conditions [3]. A cryptic complex of species were found to cause gray mold and the core species, B. cinerea, has been genetically separated into distinct groups ( $\mathrm{N}$ and S). Repeated fungicide applications have resulted in a drastic increase of multiple resistances in Botrytis isolates $[4,5]$. The filamentous ascomycete Roesleria subterranea causes root rot in grapevines and fruit trees. Because infected plants die suddenly after two or three years and efficient control methods are not available 
at present, this pathogen leads to considerable economic losses [6]. Eutypa lata is the causal agent of dead arm disease on vines and is able to infect other plants, (e.g., olives and apricots) [7]. Often, years pass between infection and the first visible signs of a disease [8]. The phytopathogenic fungus Magnaporthe oryzae is responsible for enormous crop losses in rice plants and Monilinia fructigena in stone fruits [9].

It is a permanent challenge to protect crops and foodstuffs against attack by pathogens through a variety of chemical and natural methods. The demand for biological measures is constantly increasing, as chemicals are often not safe for humans and the environment [10-12]. Moreover, fungi can develop resistance to chemical antifungal agents [4,5]. In biological control, living organisms and their metabolites or botanicals are used to control pathogens on fruit and plants. This strategy appears to be a promising alternative to conventional methods alone or as part of integrated pest management [12,13]. A wide range of bacteria (e.g., Bacillus, Pseudomonas, and Streptomyces), filamentous fungi (e.g., Trichoderma, Gliocladium, Chlonostachys, and Ulocladium), and yeasts (e.g., Aureobasidium and Candida) have been reported to exhibit inhibitory activity against fungus-incited diseases [10-21]. Especially with regard to wine production, yeasts as natural inhabitants of grapes and vine [22] appear less problematic than bacteria and fungi. The phenomenon of antagonistic activity in yeasts was first observed in the genus Saccharomyces cerevisiae. Some strains are able to inhibit the growth of sensitive strains of the same species by secreting a proteinaceous "killer toxin" [23]. Ever since its discovery, this phenomenon has been studied intensively to open the way for new approaches in yeast biopesticide research. The antifungal properties are not based on a single activity pattern of the yeasts, but also involve competition for food and space and production of volatile secondary metabolites (e.g., ethanol, ethyl acetate, and $\mathrm{CO}_{2}$ ) or lytic enzymes $[10,11,24]$.

Examples of currently registered biocontrol/biopreservation products consisting of yeast or yeast-like fungi as active ingredient are Aspire ${ }^{\circledR}$ (Candida oleophila), Candifruit ${ }^{\circledR}$ (Candida sake), Shemer ${ }^{\circledR}$ (Metschnikowia fructicola), and BoniProtect ${ }^{\circledR}$ (Aureobasidium pullulans). The great potential of Pichia anomala (syn. Wickerhamomyces anomalus) and other antagonistic yeasts has yet to be manifested in the form of available products for plant protection $[17,18]$. The successful application of a BCA depends on temperature, humidity, season, and many other environmental factors that must be considered [12,25]. Thus, the effectiveness of a product from one year or season to the next can vary to a large extent and there is a constant demand for novel products with potential biocontrol properties. Therefore, we investigated the possible inhibitory effects of yeasts originating from different environments against some phytopathogenic fungi. Particularly, we included organisms that have been paid less attention in comparable studies, such as intestinal yeasts from termites, fungi associated with serious grapevine diseases (Eutypa lata, Roesleria subterranea), and Magnaporthe oryzae, the most destructive agent of rice worldwide [9]. The main focus of this work was the search for possible, novel BCA candidates and their target organisms.

\section{Materials and Methods}

In this investigation, we use the terms "yeasts" and "fungi" for simplicity to differentiate between unicellular and filamentous growing fungi. All chemicals were purchased from Roth (Karlsruhe, Germany) or Sigma-Aldrich (Munich, Germany).

\subsection{Yeasts, Fungi, and Culture Conditions}

The yeast strains used in this investigation have been isolated from different environmental habitats over a period of several decades and are deposited at the local culture collection of the Institute of Molecular Physiology, Johannes Gutenberg-University Mainz (Table 1). Species identifications were originally performed by physiological tests and have been later confirmed for most strains by PCR amplification and sequencing of the internal transcribed spacer (ITS 1-5.8S-ITS 2) region. DNA was isolated from the pure cultured cells using an InstaGene ${ }^{\mathrm{TM}}$ Matrix kit (Bio-Rad, Munich, Germany), according to the manufacturer's protocol. Amplification of the ITS region was performed in 
a mastercycler gradient thermocycler (Eppendorf, Hamburg, Germany) with oligonucleotide primers ITS 4 (5'-TCCTCCGCTTATTGATATGC-3') and ITS 5 (5'-GGAAGTAAAAGTCGTAACAAGG-3'. The following PCR conditions were used: pre-denaturation for $5 \mathrm{~min}$ at $95^{\circ} \mathrm{C}$, followed by 35 cycles for $1 \mathrm{~min}$ at $94^{\circ} \mathrm{C}$, afterwards annealing for $1 \mathrm{~min}$ at $55^{\circ} \mathrm{C}$ and extension for $1 \mathrm{~min}$ at $72{ }^{\circ} \mathrm{C}$, and finally, a post-extension step for $10 \mathrm{~min}$ at $72^{\circ} \mathrm{C}$.

Table 1. Yeast strains investigated as putative antagonistic microorganisms.

\begin{tabular}{|c|c|c|}
\hline Species/Strain & Habitat & References \\
\hline Candida sake $2 / 42$ & roach & [26] \\
\hline Debaryomyces hansenii var. fabryii 525 & cherry & [27] \\
\hline Hanseniapora uvarum 469 & pear & [28] \\
\hline Hanseniapora uvarum 470 (ATCC 64295) & raspberry & [28] \\
\hline Hanseniapora uvarum 471 & peach & [28] \\
\hline Hanseniapora uvarum 473 & apple & \\
\hline Hanseniapora uvarum 486 & grape & \\
\hline Hanseniapora uvarum 527 & grape & [29] \\
\hline Kluyveromyces marxianus 118 & grape & \\
\hline Kluyveromyces thermotolerans 76 & grape (Crete) & \\
\hline Metschnikowia pulcherrima 152 & apple & \\
\hline Metschnikowia pulcherrima 160 & grape & \\
\hline Metschnikowia pulcherrima 192 & unknown & \\
\hline Metschnikowia pulcherrima 2305 & unknown & \\
\hline Metschnikowia pulcherrima 446 & grape & [30] \\
\hline Metschnikowia pulcherrima 523 & grape & \\
\hline Metschnikowia pulcherrima 648 & grape & \\
\hline Pichia anomala 457 (NCYC 435) & unknown & [15] \\
\hline Pichia kluyveri 2143 & apple & \\
\hline Pichia kluyveri var. kluyveri 395 (CBS 7145, ATCC 66811) & grape & [29] \\
\hline Pichia methanolica H1/3-1 & cherry & \\
\hline Torulaspora delbrueckii 3/40 & cherry & \\
\hline Wickerhamomyces anomalus 15 & apple & \\
\hline Wickerhamomyces anomalus 227 & grape & [30] \\
\hline Wickerhamomyces anomalus AS1 (DSM 28943) & grape & {$[31,32]$} \\
\hline Wickerhamomyces anomalus H.3.2 & wheat flour (Spain) & \\
\hline Wickerhamomyces anomalus WH 1021 & praline & [33] \\
\hline Williopsis californica $3 / 62$ & cherry & \\
\hline Williopsis saturnus var. makrii 458 (NCYC 500) & soil (Papua New Guinea) & [15] \\
\hline Zygosaccharomyces bailii 412 (CBS 6708) & orange (Brasil) & \\
\hline Zygosaccharomyces bailii 550 & grape & \\
\hline Apiotrichum mycotoxinovorans MYG & termite & {$[34,35]$} \\
\hline Apiotrichum mycotoxinovorans MD123D & termite & {$[34,35]$} \\
\hline Naganishia albida OO1 & termite & [35] \\
\hline Papiliotrema odontotermitis OO5 (DSM $100791^{\mathrm{T}}, \mathrm{CBS} 14181^{\mathrm{T}}$ ) & termite & [35] \\
\hline Saitozyma flava $\mathrm{OO} 2$ & termite & [35] \\
\hline Sugiyamaella mastotermitis MD39V (DSM $100793^{\mathrm{T}}, \mathrm{CBS} 14182^{\mathrm{T}}$ ) & termite & [35] \\
\hline Sugiyamaella smithiae NM1 & termite & [35] \\
\hline
\end{tabular}

Filamentous fungi (Table 2) were obtained from CBS (Centraalbureau voor Schimmelculture, Westerdijk Fungal Biodiversity Centre, Utrecht, The Netherlands), ISA (Instituto Superior de Agronomia, Lisboa, Portugal), IBWF (Institut für Biotechnologie und Wirkstoff-Forschung, Kaiserslautern, Germany), or DSMZ (Leibniz-Institut DSMZ-Deutsche Sammlung von Mikroorganismen und Zellkulturen GmbH, Braunschweig, Germany).

Yeasts were cultured in YPD medium (yeast extract $10 \mathrm{~g} / \mathrm{L}$, peptone $20 \mathrm{~g} / \mathrm{L}$, and glucose $20 \mathrm{~g} / \mathrm{L}$ ) and fungi in potato dextrose broth (PDB; Roth, Germany). Solid media were prepared with $15 \mathrm{~g} / \mathrm{L}$ agar. 
Table 2. Plant-pathogenic fungi used as target organisms.

\begin{tabular}{lcc}
\hline \multicolumn{1}{c}{ Fungal Strain } & Habitat & Source \\
\hline Botrytis cinerea V15 & Vitis vinifera & ISA \\
Botrytis cinerea V19 & Vitis vinifera & ISA \\
Botrytis cinerea V27 & Vitis vinifera & ISA \\
Botrytis cinerea B16-14 & Vitis vinifera & ISA \\
Botrytis cinerea DSM 877 & unknown & DSMZ \\
Monilinia fructigena DSM 2677 & Malus & DSMZ \\
Magnaporthe oryzae 7015 & Oryza sativa & IBWF \\
Eutypa lata 1190 & Vitis vinifera & IMWF \\
Eutypa lata 16012 & Vitis vinfera & IBWF \\
Roesleria subterranea CBS 201.25 & Vitis vinifera & CBS \\
Roesleria subterranea CBS 271.82 & Populus & CBS \\
Roesleria subterranea CBS 320.33 & Malus & CBS \\
Roesleria subterranea CBS 339.96 & shrub & CBS \\
\hline
\end{tabular}

\subsection{Preparation of Fungal Spore Suspensions}

After incubation for 14 days at $20^{\circ} \mathrm{C}$, fungal mycelia and spores were scraped from well-grown potato dextrose agar (PDA) plates and transferred to falcon ${ }^{\circledR}$ tubes containing $10 \mathrm{~mL}$ of sterile water. The suspensions were homogenized by vortexing to release conidia from the mycelium and filtered through two layers of Miracloth ${ }^{\circledR}$ (MilliporeSigma, Munich, Germany) in order to obtain spore suspensions $\left(\approx 10^{6}\right.$ spores $\left./ \mathrm{mL}\right)$.

\subsection{Enzymatic Activites}

The enzymatic activities of yeasts and fungi were visualized on agar plates containing specific enzyme substrates [36-38]. Yeasts were tested by dropping $10 \mu \mathrm{L}$ of an YPD culture on these plates, which were incubated at $30^{\circ} \mathrm{C}$ for 3-5 days. For filamentous fungi, agar plugs of $2-4 \mathrm{~mm}^{2}$ were cut out from mycelium grown on the PDA plates, placed in the center of the diagnostic enzyme plates, and incubated at $20^{\circ} \mathrm{C}$ for $4-14$ days.

\subsection{1. $\beta$-Glucosidase Activity}

Agar medium (5.0 g of esculin, $20.0 \mathrm{~g}$ of peptone from meat, $10.0 \mathrm{~g}$ of yeast extract, and $12.0 \mathrm{~g}$ of agar) were solubilized in $990 \mathrm{~mL}$ of deionized water on a magnetic stirrer at $100{ }^{\circ} \mathrm{C}$, adjusted to $\mathrm{pH} 5.0$, and autoclaved $\left(20 \mathrm{~min}\right.$ at $\left.121^{\circ} \mathrm{C}\right)$. Before pouring into petri dishes, $10 \mathrm{~mL}$ of sterile-filtered ammonium iron(III) citrate solution $(1.0 \% w / v)$ were added.

A dark brownish halo can be observed in $\beta$-glucosidase-positive yeasts. The enzyme $\beta$-glucosidase converts the esculin in the plate to esculetin and glucose. The released esculetin forms a dark complex with iron from the ammonium iron(III) citrate.

\subsubsection{Cellulase Activity}

Agar medium (5.0 g of carboxymethylcellulose sodium salt (CMC), $10.0 \mathrm{~g}$ of yeast extract, $20.0 \mathrm{~g}$ of peptone from meat, and $15.0 \mathrm{~g}$ of agar) were solubilized in $1000 \mathrm{~mL}$ of deionized water on a magnetic stirrer at $100{ }^{\circ} \mathrm{C}$, adjusted to $\mathrm{pH} 5.0$, and autoclaved $\left(20 \mathrm{~min}\right.$ at $\left.121^{\circ} \mathrm{C}\right)$. For evaluation, the plate was first treated with $0.2 \%(w / v)$ congo red solution. The dye was poured off after $10 \mathrm{~min}$ of exposure time, and the plate was decolorized by several treatments with $1 \mathrm{M} \mathrm{NaCl}$. As a result, clear hydrolysis zones were visible at the sites where cellulase activity degraded the substrate, whereas the non-modified CMC background remained orange-red colored. 


\subsubsection{Amylase Activity}

Agar medium (10.0 g of yeast extract, $20.0 \mathrm{~g}$ of peptone from meat, $20.0 \mathrm{~g}$ of starch, and $12.0 \mathrm{~g}$ of agar) were solubilized in $1000 \mathrm{~mL}$ of deionized water on a magnetic stirrer at $100{ }^{\circ} \mathrm{C}$, adjusted to $\mathrm{pH} 5.0$, and autoclaved $\left(20 \mathrm{~min}\right.$ at $\left.121^{\circ} \mathrm{C}\right)$.

The amylase plates were overlaid with Lugol's solution (iodine-potassium iodide solution) before evaluation. After $3 \mathrm{~min}$ of exposure, Lugol's solution was drained off, and the plates were allowed to stand for at least $30 \mathrm{~min}$. Over time, a bright lysis zone was observed for amylase-positive organisms, while the rest of the plate remained violet in color as the dye solution stained the unmodified starch.

\subsubsection{Protease Activity}

Agar medium (1.0 g of yeast extract, $10.0 \mathrm{~g}$ of skimmed milk powder, $4.0 \mathrm{~g}$ of peptone from meat, and $10.0 \mathrm{~g}$ of agarose) were solubilized in $1000 \mathrm{~mL}$ of citrate-phosphate buffer $(100 \mathrm{mM}, \mathrm{pH}$ 5.0: $10.1 \mathrm{~g} / \mathrm{L}$ citric acid $\left.\cdot \mathrm{H}_{2} \mathrm{O}, 18.8 \mathrm{~g} / \mathrm{L} \mathrm{NaHPO}{ }_{4} \cdot 2 \mathrm{H}_{2} \mathrm{O}\right)$ on a magnetic stirrer at $100{ }^{\circ} \mathrm{C}$, and autoclaved $\left(5 \mathrm{~min}\right.$ at $121^{\circ} \mathrm{C}$ ). For protease-positive organisms, a translucent lysis court was identified after incubation, in which the proteases degraded the milk protein.

\subsubsection{Chitinase Activity}

Agar medium $\left(2.0 \mathrm{~g}\right.$ of $\mathrm{NaNO}_{3}, 1.0 \mathrm{~g}$ of $\mathrm{K}_{2} \mathrm{HPO}_{4}, 0.5 \mathrm{~g}$ of $\mathrm{MgSO}_{4} \cdot 7 \mathrm{H}_{2} 0 ; 0.5 \mathrm{~g}$ of $\mathrm{KCl}, 0.2 \mathrm{~g}$ of peptone from meat, $10.0 \mathrm{~g}$ of chitin, and $15.0 \mathrm{~g}$ of agar) were suspended in $1000 \mathrm{~mL}$ of deionized water on a magnetic stirrer at $100{ }^{\circ} \mathrm{C}$, adjusted to $\mathrm{pH} 5.0$, and autoclaved $\left(20 \mathrm{~min}\right.$ at $121^{\circ} \mathrm{C}$ ). The chitin plates were overlaid with Lugol's solution prior to evaluation. The solution was poured off after 3 min of exposure time. In the case of chitinase secretion, distinct lysis zones formed around the colonies. The remainder of the plate remained dark as the dye solution reacted with chitin, and a brownish yellow color became visible by this reaction.

\subsection{Antagonistic Activity of Yeasts against Phytopathogenic Fungi on Agar Plates}

The "killer stroke" method was performed as described elsewhere [14,39]. The antagonistic effect of the yeasts was tested on the PDA plates. In order to evaluate the effect of iron depletion on fungal growth, the PDA was prepared without and with $5.0 \mathrm{mg} / \mathrm{L}, 10 \mathrm{mg} / \mathrm{L}$, and $20 \mathrm{mg} / \mathrm{L} \mathrm{FeCl}_{3}[40,41]$. On dried plates, each yeast strain was applied in the form of a center streak and incubated for two days at $30{ }^{\circ} \mathrm{C}$. The fungi were cut as 5-mm-wide and 5-mm-long mycelium plugs from well-grown PDA plates with a lancet and placed about $2-3 \mathrm{~cm}$ to the right and left of the yeast screed. Depending on the type of fungus, the plates were incubated for 1 to 4 weeks at $20^{\circ} \mathrm{C}$. The aim of the experiments was to find out whether fungal growth was inhibited on the PDA and whether the addition of different iron concentrations in the medium attenuated the inhibitory effect.

\subsection{Preparation of Fungal Cell Wall Components}

The fungi used here were found to be susceptible in previous experiments $(B$. cinerea strains DSM 877 and B16-14). Rough cell wall preparations were obtained following the procedure described by Chan and Tian [42] with some modifications. First, $50 \mathrm{~mL}$ of PDA liquid medium in Erlenmeyer flasks were inoculated with $1.0 \mathrm{~mL}$ of a fungal spore suspension $\left(10^{6}\right.$ spores $\left./ \mathrm{mL}\right)$. The flasks were incubated stationary at $20^{\circ} \mathrm{C}$ for 7-14 days. Thereafter, the culture suspension was rinsed through a paper filter and washed twice with sterile water. The washed biomass was placed in a $50 \mathrm{~mL}$ falcon ${ }^{\circledR}$ tube, filled up to the $10 \mathrm{~mL}$ mark with sterile water, and autoclaved $\left(20 \mathrm{~min}\right.$ at $\left.121^{\circ} \mathrm{C}\right)$. The inactivated fungal cells were disrupted by ultrasound treatment (Sonifier 250; Branson Ultraschall, Dietzenbach, Germany) for $10 \mathrm{~min}$. The falcon ${ }^{\circledR}$ tube was frozen at $-20{ }^{\circ} \mathrm{C}$ and then placed in a freeze-drying apparatus (Lyovac GT 2; Steris GmbH, Köln, Germany) for 1-2 days. After determining the mycelium dry weight, the fungal material was suspended in $10 \mathrm{~mL}$ of sterile water and homogenized again by 
sonification. The fungal cell wall material was tested for possible induction of extracellular antagonistic factors in yeast liquid cultures.

\subsection{Preparation of Cell-Free Culture Filtrates}

In order to assess whether inhibition involves secreted antimicrobial agents or lytic enzymes, the culture filtrates of yeasts were concentrated by three different procedures: lyophilization, ultrafiltration, and extraction with ethyl acetate.

\subsubsection{Lyophilization}

For the cultivation of yeasts, baffled flasks were used with $250 \mathrm{~mL}$ of YPD medium each. Putative induction of extracellular antagonistic factors was assessed in culture media prepared with $0.1 \%(w / v)$ fungal cell wall material. The flasks were inoculated with $1.0 \%(v / v)$ of a preculture and incubated at $30{ }^{\circ} \mathrm{C}$ on a shaker for five days. Subsequently, the culture suspensions were centrifuged (12 min, $8600 \mathrm{~g}$ ), and the supernatants were passed through a $0.2 \mu \mathrm{m}$ vacuum filter unit. The sterile supernatants were filled in dialysis tubing with a pore size of $3.0 \mathrm{kDa}$ and dialyzed for three days at $5{ }^{\circ} \mathrm{C}$ against deionized water. Thereafter, the dialysates were poured in round-bottom flasks, frozen at $-20{ }^{\circ} \mathrm{C}$ and then left for 1-2 days to freeze dry, and lyophilizates were dissolved in $10 \mathrm{~mL}$ of sterile water. The concentrated culture supernatants, which should contain molecules $>3 \mathrm{kDa}$ were tested in agar diffusion assays. Sterile YPD medium was applied as a control. The plates were incubated 4-14 days at $20^{\circ} \mathrm{C}$.

\subsubsection{Ultrafiltration}

First, $50 \mathrm{~mL}$ of fresh yeast cultures were centrifuged $(12 \mathrm{~min}, 8600 \mathrm{~g})$, and the supernatants were rinsed through a paper filter. The supernatants were filtered through a $10 \mathrm{kDa}$ Vivaspin ${ }^{\circledR}$ concentrator (Sartorius, Göttingen, Germany) for $3 \mathrm{~h}$ at $8600 \mathrm{~g}$. The permeates of Vivaspins ${ }^{\circledR}$ were collected and freeze dried. The dry material was balanced, dissolved in $5.0 \mathrm{~mL}$ of water, and sterilized by filtration (pore size $0.2 \mu \mathrm{m}$ ).

The Vivaspin ${ }^{\circledR}$ retentate, the Vivaspin ${ }^{\circledR}$ permeate, and the concentrated Vivaspin ${ }^{\circledR}$ permeate were tested using the agar diffusion test. As a control, sterile YPD medium was pipetted into one of the wells. The plates were incubated for $4-14$ days at $20^{\circ} \mathrm{C}$.

\subsubsection{Extraction with Ethyl Acetate}

First, $200 \mathrm{~mL}$ of a three-day-old yeast culture in YPD were centrifuged $\left(30 \mathrm{~min}\right.$ at $4{ }^{\circ} \mathrm{C}$ and $17,700 \mathrm{~g}$ ). The supernatant was placed in a separatory funnel, and $250 \mathrm{~mL}$ of ethyl acetate were added. This mixture was incubated for $30 \mathrm{~min}$ and shaken several times. Finally, the lower, aqueous phase was drained off. The ethyl acetate phase was transferred to a $1000 \mathrm{~mL}$ round-bottom flask through a paper filter to which $60 \mathrm{~g}$ of sodium sulfate were added to bind the water. The extract was concentrated with the aid of a rotary evaporator (Büchi, Essen, Germany) to dryness. The concentrated substances were dissolved in $3.0 \mathrm{~mL}$ of methanol. The solution was transferred to sample vessels and placed in a vacuum concentrator (Eppendorf, Hamburg, Germany). After evaporation of the methanol, the dry weight was determined, and the material was dissolved in $2.0 \mathrm{~mL}$ of sterile water and $100 \mu \mathrm{L}$ of dimethylsulfoxide (DMSO).

The solution with potentially active substances was tested using an agar diffusion assay. As a negative control, DMSO $(5.0 \% v / v)$ was pipetted into one of the wells. As a positive control, the herbicide BASTA ${ }^{\circledR}$ (Bayer, Leverkusen, Germany) was used in a final concentration of $2 \mathrm{mg} / \mathrm{mL}$. The plates were incubated $4-14$ days at $20^{\circ} \mathrm{C}$. 


\subsection{Agar Diffusion Assay}

First, $100 \mu \mathrm{L}$ of a fungal spore suspension $\left(10^{6}\right.$ spores $\left./ \mathrm{mL}\right)$ were spread on the PDA plates, and after incubation at room temperature for $24 \mathrm{~h}$, holes were punched out and filled with $100 \mu \mathrm{L}$ of the test substances. The plates were incubated at $20^{\circ} \mathrm{C}$ for 3-14 days, depending on the growth of the fungi. Antagonistic activity was easily recognized by a growth inhibition zone around the holes containing test substances.

\subsection{Antagonistic Activities on Fruits}

The model experiment with apples followed the procedure described by Zhang et al. [43]. Holes were punched into each of ten apples with a sterile pipette tip and filled by means of a syringe with the appropriate samples: (a) control with $200 \mu \mathrm{L}$ of sterile water; (b) $200 \mu \mathrm{L}$ of sterile filtered culture supernatant; (c) $200 \mu \mathrm{L}$ of fungal spore suspension; (d) $100 \mu \mathrm{L}$ of fungal spore suspension $+100 \mu \mathrm{L}$ of sterile filtered culture supernatant; and (e) $100 \mu \mathrm{L}$ fungal spore suspension $+100 \mu \mathrm{L}$ yeast suspension. The apples were incubated for seven days at room temperature. For evaluation, the fruits were cut with a knife so that the puncture holes were visible in the longitudinal section. Due to the growth of the fungus, it became brown and rotten in the apple at the puncture site. In the case of antagonistic activity of the yeast against the fungus, this rot was reduced or even prevented.

For the grape trials, three samples were prepared: $10 \mathrm{~mL}$ of yeast suspension, $10 \mathrm{~mL}$ of sterile filtered culture supernatant, and $10 \mathrm{~mL}$ of YPD medium (control). Nine grapes were prepared by washing with $70 \%(v / v)$ ethanol. Thereafter, they were punctured by a sterile needle eight times at regular intervals. The punctured grapes were placed in the three media for $2-3 \mathrm{~h}$. The grapes were removed from the solutions under sterile conditions, left briefly to allow liquids to dry on the grape, halved, and then exposed to the PDA plates previously seeded with $100 \mu \mathrm{L}$ of a fungal spore suspension $\left(10^{6}\right.$ spores $\left./ \mathrm{mL}\right)$. Control grapes were exposed to the PDA plates that had not previously been inoculated with the fungal spores and mycelium.

The plates were incubated at room temperature for seven days. Antagonistic activities were detected by a zone of growth inhibition around the grape.

\section{Results and Discussion}

We assessed the antagonistic activity of 38 yeasts strains from different habitats (wine, fruits, soil, and termite gut) against 12 fungal strains representing the phytopathogenic species $B$. cinerea, $M$. fructigena, E. lata, R. subterranea, and M. oryzae. Some typical results of the in vitro experiments on agar plates are shown in Figure 1 and are summarized in Table 3.
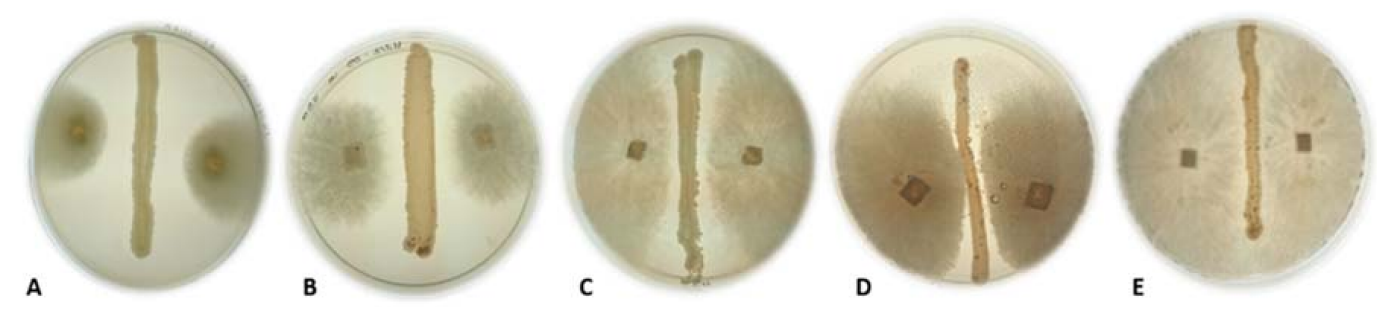

Figure 1. Patterns of antagonistic interaction between yeasts and phytopathogenic fungi grown on potato-dextose agar. (A) P. anomala 457 vs. E. lata 16012 (+++); (B) Z. bailii 550 vs. E. lata 1190 (++); (C) C. sake H1/3-29 vs. B. cinerea 16-14 (+); (D) C. sake H1/3-29 vs. B. cinerea 877 ( \pm ); (E) P. methanolica H1/3-1 vs. R. subterranea CBS 339.96 (-). The fungus is strongly inhibited (+++) when growing away from the yeast on both sides; the mycelium of the fungus does not reach the yeast, and the inhibition zone between fungus and yeast is about 1.0 and $2.0 \mathrm{~cm}$. Medium inhibition (++) when the fungus grows away from the yeast; the inhibition zone is between 0.5 and $1.0 \mathrm{~cm}$. Slight inhibition (+) when there is a distance between 0.2 and $0.5 \mathrm{~cm}$ between fungus and yeast. The fungus is not inhibited (-) when growing unrestrained on the agar plate in direction of yeast. 
Table 3. Antagonistic activities of yeasts against fungi as observed on agar plates.

\begin{tabular}{|c|c|c|c|c|c|c|c|c|c|c|c|c|}
\hline \multicolumn{13}{|c|}{ Fungal Strain } \\
\hline Yeast Strain & $\begin{array}{l}\text { B. cinerea } \\
\text { V15 }\end{array}$ & $\begin{array}{l}\text { B. cinerea } \\
\text { V19 }\end{array}$ & $\begin{array}{l}\text { B. cinerea } \\
\text { V27 }\end{array}$ & $\begin{array}{c}\text { B. cinerea } \\
16-14\end{array}$ & $\begin{array}{l}\text { B. cinerea } \\
\text { DSM } 877\end{array}$ & $\begin{array}{l}\text { M. fructigena } \\
\text { DSM } 2677\end{array}$ & $\begin{array}{c}\text { M. oryzae } \\
7015\end{array}$ & $\begin{array}{c}\text { E. lata } \\
1190\end{array}$ & $\begin{array}{l}\text { E. lata } \\
16012\end{array}$ & $\begin{array}{l}\text { R. subterranea } \\
\text { CBS } 271.82\end{array}$ & $\begin{array}{l}\text { R. subterranea } \\
\text { CBS } 320.33\end{array}$ & $\begin{array}{l}\text { R. subterranea } \\
\text { CBS } 339.96\end{array}$ \\
\hline M. pulcherrima 160 & + & - & - & ++ & ++ & ++ & +++ & + & nd & ++ & ++ & ++ \\
\hline M. pulcherrima 446 & ++ & - & - & ++ & +++ & ++ & +++ & + & nd & +++ & ++ & +++ \\
\hline M. pulcherrima 648 & +++ & - & + & ++ & +++ & ++ & +++ & - & nd & + & + & + \\
\hline M. pulcherrima 152 & +++ & - & + & +++ & +++ & ++ & ++ & - & nd & +++ & +++ & +++ \\
\hline M. pulcherrima 192 & +++ & - & + & ++ & +++ & ++ & ++ & - & nd & ++ & - & - \\
\hline M. pulcherrima 523 & + & - & - & + & ++ & + & ++ & - & nd & + & - & - \\
\hline M. pulcherrima 2305 & + & - & - & ++ & ++ & + & +++ & + & nd & +++ & ++ & + \\
\hline C. sake $2 / 42$ & - & - & + & + & +++ & + & - & - & - & ++ & + & - \\
\hline P. anomala 457 & +++ & - & + & ++ & - & +++ & ++ & ++ & +++ & nd & nd & - \\
\hline P. kluyveri 2143 & ++ & - & + & ++ & +++ & - & +++ & - & - & - & - & - \\
\hline P. kluyveri 395 & ++ & - & - & ++ & - & - & +++ & - & - & + & - & + \\
\hline P. methanolica $\mathrm{H} 1 / 3-1$ & + & - & +++ & + & ++ & - & +++ & - & - & + & nd & - \\
\hline Z. bailii 412 & + & - & - & + & +++ & + & +++ & - & - & + & - & + \\
\hline Z. bailii 550 & - & - & - & - & + & - & +++ & + & - & + & - & - \\
\hline W. anomalus AS1 & _- & _- & +++ & ++ & +++ & ++ & +++ & - & - & ++ & +++ & +++ \\
\hline W. anomalus H.3.2 & - & - & +++ & +++ & +++ & + & +++ & - & - & + & ++ & + \\
\hline W. anomalus WH 1021 & - & - & +++ & ++ & +++ & + & +++ & - & - & + & + & +++ \\
\hline W. anomalus 15 & + & - & +++ & ++ & +++ & + & +++ & - & - & ++ & ++ & +++ \\
\hline W. anomalus 227 & + & + & - & ++ & +++ & - & +++ & - & - & ++ & +++ & +++ \\
\hline W. californica $3 / 62$ & - & - & ++ & + & + & ++ & - & - & - & - & ++ & ++ \\
\hline W. saturnus 458 & - & - & - & + & ++ & ++ & - & - & - & + & + & - \\
\hline T. delbrueckii $3 / 40$ & - & - & +++ & + & ++ & - & +++ & - & - & - & - & - \\
\hline K. thermotolerans 76 & - & - & - & - & - & - & - & - & - & - & - & - \\
\hline K. marxianus 118 & - & - & + & - & + & + & - & - & - & - & + & - \\
\hline H. uvarum 469 & - & - & ++ & + & + & + & ++ & ++ & + & ++ & - & - \\
\hline H. uvarum 470 & - & - & + & - & + & ++ & - & - & - & - & - & - \\
\hline H. uvarum 471 & - & - & ++ & - & ++ & ++ & ++ & + & ++ & - & - & - \\
\hline H. uvarum 473 & - & - & ++ & + & + & + & ++ & + & ++ & + & - & - \\
\hline H. uvarum 486 & - & - & - & - & ++ & + & - & + & + & - & - & - \\
\hline H. uvarum 527 & - & - & + & - & ++ & + & - & + & + & - & - & - \\
\hline D. hansenii 525 & - & - & + & - & + & - & - & - & - & - & - & - \\
\hline A. mycotoxinovorans MYG & - & + & + & - & + & - & - & - & - & - & - & - \\
\hline A. mycotoxinovorans MD123D & - & - & + & - & + & - & - & - & - & - & - & - \\
\hline N. albida $\mathrm{OO} 1$ & - & - & + & + & + & + & - & - & - & - & - & + \\
\hline P. odontotermitis OO5 & + & - & + & ++ & + & + & - & - & - & - & - & - \\
\hline S. flava $\mathrm{OO} 2$ & + & - & + & + & + & - & - & - & - & - & - & - \\
\hline S. mastotemitis MD39V & - & - & + & + & + & - & - & - & - & - & - & + \\
\hline S. smithiae NM1 & - & - & + & - & + & - & + & - & - & - & - & - \\
\hline
\end{tabular}

For genus abbreviations, see Tables 1 and 2. The evaluation of the results followed the scheme described in Figure 1; nd: not determined. 
It is evident that the growth of each of the pathogenic fungi was inhibited by at least one yeast species to a different extent. Some fungal strains (M. oryzae 7015, M. fructigena DSM 2677, and $B$. cinerea strains V27, 16-14, and DSM 877) proved to be sensitive to many yeast strains, whereas others (B. cinerea V15 and V19; E. lata strains 1190 and 16012; and R. subterranea strains CBS 271.82, 320.33, and CBS 339.96) were inhibited by a restricted number of yeast strains. There is a remarkable difference among the sensitivity of the five $B$. cinerea strains. This divergent behavior may reflect the broad population diversity of this pathogen, which is structured not only by the host plant, but also by the cropping system, geography, and fungicide applications [44]. Strain DSM 877 may present a special case, because it is a laboratory strain used for biotechnological purposes and is probably less adapted to natural environments than the others.

Regarding the yeasts, strains of M. pulcherrima and W. anomalus showed a broad spectrum of antagonistic activities. Both species have been repeatedly isolated from grapes and other plants [22,45-48]. Strains of M. pulcherrima have already been suggested for biocontrol of fungal diseases on apples [49], grapes [39], sweet cherries [18], strawberries [50], mango fruits [51], and even for clinical treatment of mycoses in mammals [52].

The related species Metschnikowia fructicola has been reported to be an antagonistic organism against fungal diseases occurring after harvest $[53,54]$. Originally, it was believed that M. pulcherrima differs from its sister species $M$. fructicola by the production of the reddish pigment pulcherrimin [55], whereas later other authors have reported that both species are able to produce the compound [40]. Pulcherrimin is a chemical complex, formed between iron and pulcherriminic acid. In bacteria, pulcherriminic acid is synthesized via cyclodileucine by enzymatic condensation of two leucyl-tRNAs. Homologues of the Bacillus subtilis gene cluster could not be identified in the genome of M. fructicola, and so, the synthetic pathway has still to be elucidated in yeasts [56,57]. In contrast to common siderophores, which facilitate cellular iron uptake, pulcherriminic acid is water-soluble until it binds iron and then precipitates as the water-insoluble, red-brown pulcherrimin complex. Therefore, it was hypothesized that M. pulcherrima uses this chelating agent as a competitive factor in order to outcompete fungi and bacteria through iron depletion $[40,41,58]$.

Our results could verify these earlier reports in part. For example, addition of iron completely reversed the growth inhibition of B. cinerea V15 by M. pulcherrima 160, while vegetative growth of B. cinerea DSM 877 was not affected (Figure 2). Thus, elucidation of the mechanisms of antagonism is not always straightforward [56]. Enzymatic activities may also play a role in the antagonism (e.g., the application of a chitinase from $M$. fructicola overexpressed in Pichia pastoris counteracts brown rot fungi in peaches) [59]. Saravanakumar et al. [60] showed that a M. pulcherrima strain MACH1 has the ability to secrete chitinases in different liquid media and pointed out that the enzyme could be involved in the postharvest biocontrol of B. cinerea. In our study, we detected chitinase activities in all M. pulcherrima strains and in some other yeasts (Table 4$)$.

Wickerhamomyces anomalus (formerly Pichia anomala) is the second species in our experimental setup, for which a broad antagonistic spectrum was observed. The yeast has been extensively studied for applications against postharvest spoilage molds [15,25] and for wine biotechnology [32]. W. anomalus and other yeasts produce various volatile organic compounds (VOC), and the biocontrol activities of these microorganisms have been mainly ascribed to the action of ethyl acetate [11,50]. Furthermore, W. anomalus strains were found to inhibit the human pathogenic fungus Aspergillus flavus by secreting 2-phenyl ethanol, which prevents spore formation and reduces the biosynthesis of aflatoxins [24]. 

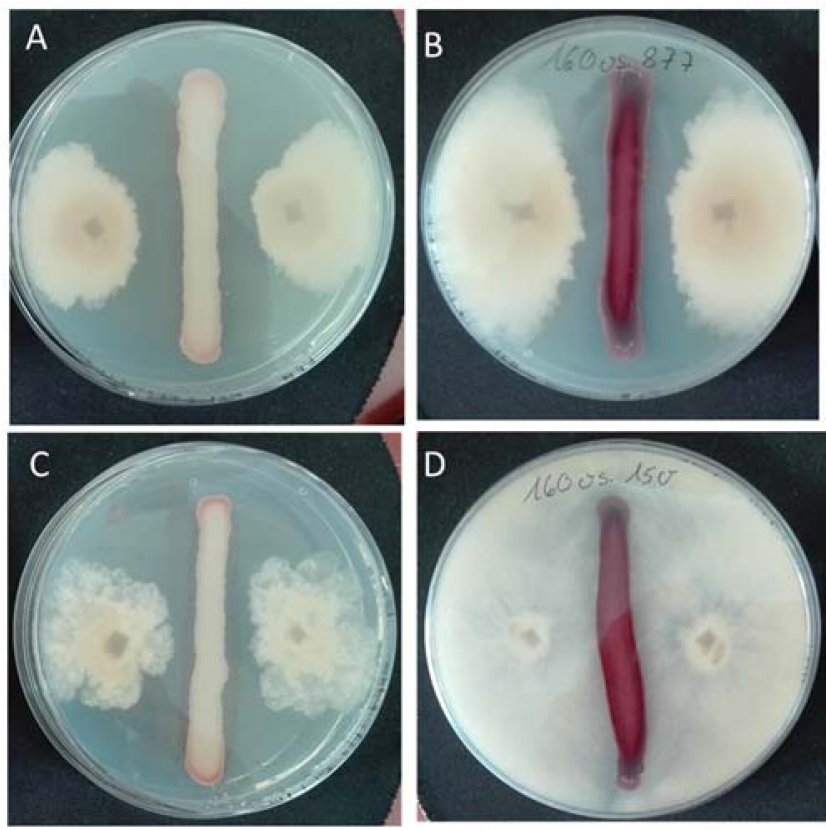

Figure 2. Antagonistic interactions on the PDA plates. M. pulcherrima 160 and B. cinerea DSM 877 in the presence of (A) $5 \mathrm{mg} / \mathrm{L} \mathrm{FeCl}_{3}$ and (B) $20 \mathrm{mg} / \mathrm{L} \mathrm{FeCl}_{3} ;$ M. pulcherrima 160 and B. cinerea $\mathrm{V} 15$ in the presence of (C) $5 \mathrm{mg} / \mathrm{L} \mathrm{FeCl}_{3}$ and (D) $20 \mathrm{mg} / \mathrm{L} \mathrm{FeCl}_{3}$.

Table 4. Extracellular enzymatic activities of the strains investigated.

\begin{tabular}{|c|c|c|c|c|c|}
\hline \multirow[b]{2}{*}{ Yeast } & \multicolumn{5}{|c|}{ Secreted Enzymatic Activity } \\
\hline & Amylase & Cellulase & $\beta$-Glucosidase & Chitinase & Protease \\
\hline M. pulcherrima 160 & ++ & - & +++ & + & ++ \\
\hline M. pulcherrima 446 & + & - & +++ & + & ++ \\
\hline M. pulcherrima 648 & +++ & - & +++ & + & +++ \\
\hline M. pulcherrima 152 & + & - & +++ & + & + \\
\hline M. pulcherrima 192 & + & - & +++ & + & ++ \\
\hline M. pulcherrima 523 & + & - & +++ & + & +++ \\
\hline M. pulcherrima 2305 & ++ & - & +++ & + & ++ \\
\hline C. sake $2 / 42$ & ++ & - & ++ & - & + \\
\hline P. anomala 457 & +++ & - & ++ & + & - \\
\hline P. kluyveri 2143 & ++ & - & ++ & - & + \\
\hline P. kluyveri 395 & ++ & + & + & - & ++ \\
\hline P. methanolica H1/3-1 & ++ & - & $\begin{array}{l}\text { T } \\
+++\end{array}$ & +++ & +++ \\
\hline Z. bailii 412 & ++ & + & ++ & - & ++ \\
\hline Z. bailii 550 & + & - & $\begin{array}{l}T_{T} \\
+\end{array}$ & - & - \\
\hline W. anomalus AS1 & + & + & + & + & +++ \\
\hline W. anomalus H.3.2 & + & + & + & + & ++ \\
\hline W. anomalus WH 1021 & + & + & + & - & ++ \\
\hline W. anomalus 15 & + & + & + & +++ & $\begin{array}{l}\text { TT } \\
++\end{array}$ \\
\hline W. anomalus 227 & + & + & + & $\begin{array}{l}\text { t+t } \\
++\end{array}$ & +t+ \\
\hline W. californica $3 / 62$ & + & + & + & - & $\begin{array}{l}\text { TTT } \\
+\end{array}$ \\
\hline W. saturnus 458 & + & + & + & ++ & - \\
\hline T. delbrueckii 3/40 & + & + & + & ++ & + \\
\hline K. thermotolerans 76 & + & + & + & + & + \\
\hline K. marxianus 118 & + & - & + & + & - \\
\hline H. uvarum 469 & - & + & + & + & + \\
\hline H. uvarum 470 & - & + & + & - & + \\
\hline H. uvarum 471 & - & + & + & + & - \\
\hline H. uvarum 473 & - & + & + & + & + \\
\hline H. uvarum 486 & - & - & + & - & $\begin{array}{l}+ \\
+\end{array}$ \\
\hline H. uvarum 527 & - & + & $\begin{array}{l}+ \\
+\end{array}$ & + & $\begin{array}{l}+ \\
+\end{array}$ \\
\hline
\end{tabular}


Table 4. Cont

\begin{tabular}{|c|c|c|c|c|c|}
\hline \multirow[b]{2}{*}{ Yeast } & \multicolumn{5}{|c|}{ Secreted Enzymatic Activity } \\
\hline & Amylase & Cellulase & $\beta$-Glucosidase & Chitinase & Protease \\
\hline D. hansenii 525 & ++ & + & + & - & + \\
\hline A. mycotoxinovorans MYG & +++ & - & ++ & - & ++ \\
\hline A. mycotoxinovorans MD123D & +++ & - & +++ & - & + \\
\hline N. albida $\mathrm{OO} 1$ & +++ & + & ++ & - & + \\
\hline P. odontotermitis OO5 & +++ & + & ++ & + & ++ \\
\hline S. flava $\mathrm{OO} 2$ & - & - & + & + & - \\
\hline S. mastotermitis MD39V & +++ & + & ++ & - & + \\
\hline S. smithiae NM1 & + & + & + & + & + \\
\hline \multicolumn{6}{|l|}{ Fungus } \\
\hline B. cinerea V15 & + & - & + & + & - \\
\hline B. cinerea V19 & + & - & + & + & - \\
\hline B. cinerea V27 & + & - & - & + & + \\
\hline B. cinerea $16-14$ & + & - & + & + & + \\
\hline B. cinerea 877 & + & - & + & + & + \\
\hline M. fructigena DSM 2677 & + & - & + & + & + \\
\hline M. oryzae 7015 & + & - & + & + & + \\
\hline E. lata 1190 & + & - & + & + & + \\
\hline E. lata 16012 & + & - & + & + & + \\
\hline R. subterranea CBS 271.82 & + & - & + & + & + \\
\hline R. subterranea CBS 320.33 & + & - & + & + & - \\
\hline R. subterranea CBS 339.96 & + & - & + & + & - \\
\hline
\end{tabular}

For genus abbreviations, see Tables 1 and 2. Evaluation: (+), (++), and (+++) mean slight, medium, and strong positive reaction zones $(>1 \mathrm{~cm})$ around the yeast colonies, respectively; $(-)$ means no detectable activity.

Antagonistic activities were also detected in the genera Candida, Debaryomyces, Pichia, Hanseniaspora, Kluyveromyces, Williopsis, and Zygosaccharomyces (Table 3), which is in line with earlier observations [10,11,14,28,29].

Yeasts that exhibited antimycotic activities on the agar plates were tested under more environmentally related conditions. As shown in Figures 3 and 4, fruits treated with yeast suspensions efficiently prevented growth of the co-inoculated phytopathogenic fungus.

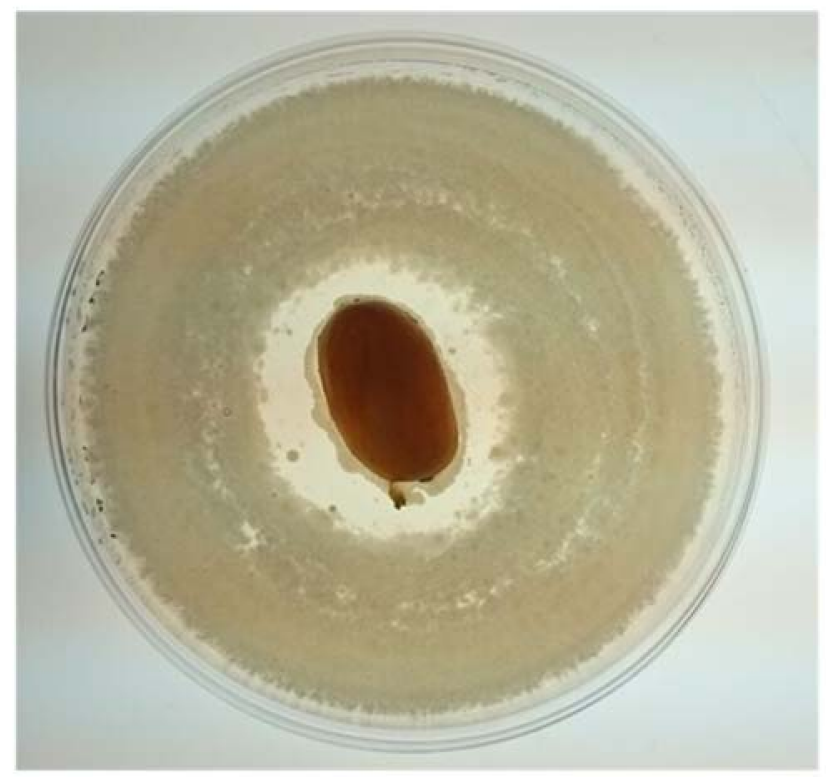

Figure 3. Antagonistic activity on fruits. The grape was soaked with a suspension of $P$. methanolica H1/3-1 and placed on PDA inoculated with spores of B. cinerea 887. Around the treated grape, a clear zone of fungal growth inhibition is evident. 

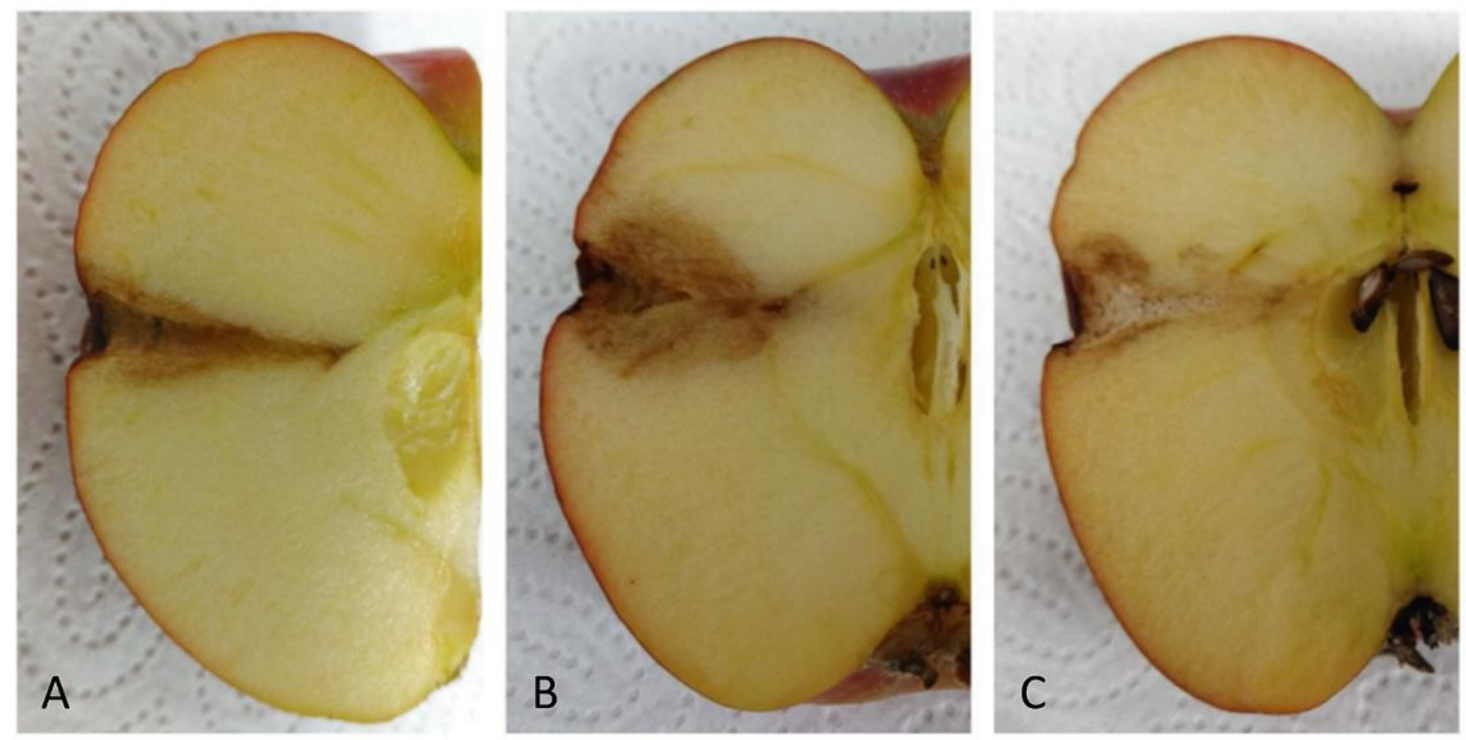

Figure 4. Antagonistic activity on fruits. Apple inoculated with P. odontotermitis OO5 (A), B. cinerea B16-14 (B), and P. odontotermitis OO5 + B. cinerea B16-14 (C). Inoculation with the fungual strain caused a brown lesion zone, which was significantly reduced by co-inoculation with the yeast.

Apart from secondary metabolites, exo- $\beta-1,3$ glucanases seem to be involved in the antagonistic action of $W$. anomalus (strain K) against B. cinerea and Penicillium expansum on apples, B. cinerea on grapes, Penicillium digitatum on oranges, and Colletotrichum gloeosporioides on papayas [11]. Nevertheless, the role of lytic enzymes as antagonistic "toxins" against fungi is a matter of debate. The results of Grevesse et al. [61] ruled out any involvement of exo- $\beta-1,3$ glucanases, whereas Friel et al. [62] demonstrated, by gene knock-out experiments, that exoglucanase PaExg2 of strain $\mathrm{K}$ is essential for the inhibition of $B$. cinerea. Zhang et al. $[63,64]$ reported antifungal activities of an exo-1,3- $\beta$-glucanase secreted by the antagonistic yeast Pichia guilliermondii and of an alkaline serine protease released by the biocontrol agent Aureobasidium pullulans PL5. It should be considered that enzyme systems for fungal cell lysis are usually a mixture of several different enzymes, including one or more $\beta-1,3-$ and $\beta$-1,6-glucanases, proteases, mannanases, or chitinases, acting synergistically to lyse the cell wall [65]. In this context, we screened for lytic exoenzymes in the organisms investigated and found significant secreted activities of different glycoside hydrolases and proteases (Table 4 ). The $\beta$-glucosidase activities may simultaneously indicate the presence of $\beta$-glucanases, as found for $W$. anomalus AS1 in our previous study [32].

Surprisingly, all attempts to demonstrate direct antagonistic activities of lytic enzymes in the yeast culture filtrates by the agar diffusion assay failed, regardless of culture conditions (non-induced or induced with fungal cell walls), and the concentration method used (lyophilization or ultrafiltration). Possible explanations may be low activities, low stabilities, diffusion barriers or enzymatic (proteolytic) inactivation by the fungi.

In contrast, we detected non-enzymatic antagonistic activities in the cultures of yeasts isolated from the guts of termites. To our knowledge, this is one of the first reports on the biocontrol potential of intestinal yeasts. Termites fed on wood, plant decay products, grass, soil, and dung. For the digestion of these materials, these insects require hydrolytic enzymes, such as cellulases and xylanases, which are predominantly supplied by microorganisms living in their digestive systems. In addition, microbes in the intestines of organisms often protect termites and other insects from attack by harmful fungi [66]. This implies potential antagonistic effects of termite yeasts against competitors. Therefore, intestinal yeasts from termites were tested in this work for antifungal activity. Termite yeasts were found to inhibit growth of B. cinerea strains on agar plates in an effective manner (Table 3, Figure 4A). In ethyl 
acetate extracts and in the concentrated ultrafiltrate fraction $(<10 \mathrm{kDa})$, we detected antagonistic activity in P. odontotermitis OO5 (Figure 4B), which is presumably due to a low molecular thermostable factor.

The termite yeasts included in this study are not obligate gut symbionts and can be efficiently cultivated under aerobic laboratory conditions. In a model experiment with apples, P. odontomtermits OO5 successfully counteracted infection by B. cinerea (Figure 5).
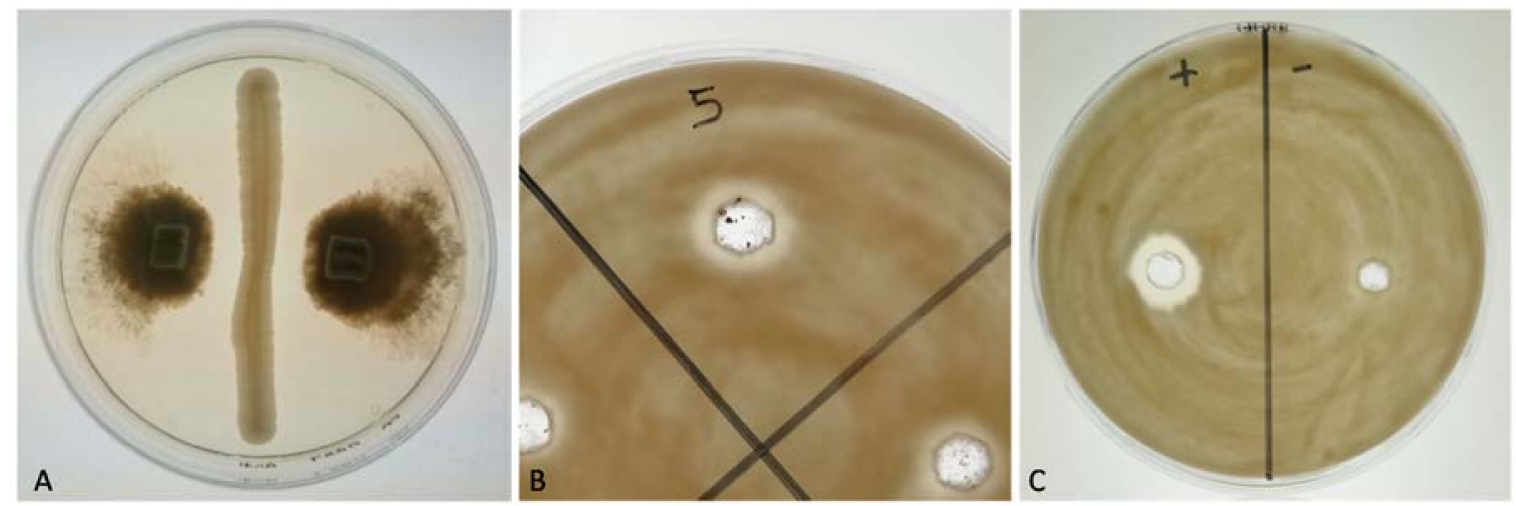

Figure 5. Antagonistic activity of P. odontotermitis OO5 against B. cinerea B16-14. (A) Growth inhibition on PDA; (B) agar diffusion assay with culture filtrate extracted with ethyl acetate; and (C) positive control (BASTA ${ }^{\circledR}$ ) and negative control ( $5 \%$ v/v DMSO).

Thus, yeasts from termite gut may present a promising group of biocontrol organisms. A practical example is A. mycotoxinivorans, which was found to degrade mycotoxins, such as ochratoxin A and zearalenone. This termite yeast has been assessed as a safe to be used as a probiotic food additive for toxin decontamination in animal feed [34,67].

\section{Conclusions}

The inhibitory effects of yeasts vary according to antagonist and environmental conditions and are based on different principles [11]. Verified inhibitory mechanisms of some yeast genera, such as the iron complexation by M. pulcherrima, are not valid for other yeasts studied here. Although exoenzyme production of the investigated yeasts is versatile, the involvement of lytic enzymes in antagonistic reactions remains essentially unclear and may depend on experimental and environmental conditions. The inhibitory activities of the yeasts were confirmed in natural environments, such as table grapes and apples, even after the freeze-drying of the yeast cultures [25]. Furthermore, mycotoxin production is generally of little concern in yeasts compared with filamentous fungi [17], and most genera have GRAS (Generally Recognized as Safe) status and are useful for food fermentations [68]. Yeasts from the original environment of the pathogens may be more active in terms of antagonistic activity than commercial killer yeasts, such as Candida oleophila. Nevertheless in the experiments presented here, termite yeasts were antagonistic to selected phytopathogenic fungi both in vitro and in model plant/fruit experiments. In particular, the observed inhibitory effect of P. odontotermitis OO5 against $B$. cinerea appears promising. Therefore, it is mandatory to investigate the identity and molecular basis of yeast antagonistic factors in more detail.

Author Contributions: Julia Pretscher, Tilman Fischkal, Sina Branscheidt, Lucas Jäger, Susann Kahl, and Martina Schlander performed the experiments; and Eckhard Thines and Harald Claus designed the experiments, analyzed data, and wrote the manuscript.

Conflicts of Interest: The authors declare no conflict of interests. 


\section{References}

1. Pozo-Bayón, M.Á.; Monagas, M.; Bartolomé, B.; Morena-Arribas, M.V. Wine features related to safety and consumer health: An integrated perspective. Crit. Rev. Food Sci. Nutr. 2012, 52, 31-54. [CrossRef] [PubMed]

2. Fillinger, S.; Elad, Y. Botrytis_-The Fungus, the Pathogen and Its Management in Agricultural Systems; Springer International Publishing AG: Basel, Switzerland, 2016.

3. Kassemeyer, H.H. Fungi of grapes. In Biology of Microorganisms on Grapes, in Must and in Wine; König, H., Unden, F., Fröhlich, J., Eds.; Springer International Publishing AG: Basel, Switzerland, 2017; pp. 103-132.

4. Kretschmer, M.; Hahn, M. Fungicide resistance and genetic diversity of Botrytis cinerea isolates from a vineyard in Germany. J. Plant Dis. Prot. 2008, 115, 214-219. [CrossRef]

5. Rupp, S.; Weber, R.W.S.; Rieger, D.; Detzel, P.; Hahn, M. Spread of Botrytis cinerea strains with multiple fungicide resistance in German horticulture. Front. Microbiol. 2016, 7. [CrossRef] [PubMed]

6. Neuhauser, S.; Huber, L.; Kirchmair, M. Is Roesleria subterranea a primary pathogen or a minor parasite of grapevines? Risk assessment and a diagnostic decision scheme. Eur. J. Plant Pathol. 2011, 130, 503-510. [CrossRef] [PubMed]

7. Fischer, J.; Thines, E. Secondary metabolites of fungal vine pathogens. In Biology of Microorganisms on Grapes, in Must and in Wine; König, H., Unden, F., Fröhlich, J., Eds.; Springer International Publishing AG: Basel, Switzerland, 2017; pp. 165-185.

8. Moisy, C.; Berger, G.; Flutre, T.; Cunff, L.L.; Péros, J. Quantitative assessment of grapevine wood colonization by the dieback fungus Eutypa lata. J. Fungi 2017, 3, 21. [CrossRef] [PubMed]

9. Dean, R.; van Kan, J.A.L.; Pretorius, Z.A.; Hammond-Kosack, K.E.; di Pietro, A.; Spanu, P.D.; Rudd, J.J.; Dickman, M.; Kahmann, R.; Ellis, J.; et al. The top 10 fungal pathogens in molecular plant pathology. Mol. Plant Pathol. 2012, 13, 414-430. [CrossRef] [PubMed]

10. Liu, J.; Sui, Y.; Wisniewski, M.; Droby, S.; Liu, Y. Review: Utilization of antagonistic yeasts to manage postharvest diseases in fruit. Int. J. Food Microbiol. 2013, 167, 153-160. [CrossRef] [PubMed]

11. Muccilli, S.; Restuccia, C. Bioprotective role of yeasts. Microorganisms 2015, 3, 588-611. [CrossRef] [PubMed]

12. Nicot, P.C.; Stewart, A.; Bardin, M.; Elad, Y. Biological control and biopesticide suppression of Botrytis-incited diseases. In Botrytis - The Fungus, the Pathogen and Its Management in Agricultural Systems; Fillinger, S., Elad, Y., Eds.; Springer International Publishing: Basel, Switzerlad, 2016; pp. 165-188.

13. Rotolo, C.; De Miccolis Angelini, R.M.; Dongiovanni, C.; Pollastro, S.; Fumarola, G.; Di Carolo, M.; Perrelli, D.; Natal, P.; Faretra, F. Use of biocontrol agents and botanicals in integrated management of Botrytis cinerea in table grape vineyards. Pest Manag. Sci. 2018, 74, 715-725. [CrossRef] [PubMed]

14. Walker, G.M.; McLeod, A.H.; Hodgson, V.J. Interactions between killer yeasts and pathogenic fungi. FEMS Microbiol. Lett. 1995, 127, 213-222. [CrossRef] [PubMed]

15. Druvefors, Ä.U.; Schnürer, J. Mold-inhibitory activity of different yeast species during airtight storage of wheat grain. FEMS Yeast Res. 2005, 5, 373-378. [CrossRef] [PubMed]

16. Rosa-Magri, M.M.; Tauk-Tornisielo, S.M.; Ceccato-Antonini, S.R. Bioprospection of yeasts as biocontrol agents phytopathogenic molds. Braz. Arch. Biol. Biotechnol. 2011, 54, 1-5. [CrossRef]

17. Sundh, I.; Melin, P. Safety and regulation of yeasts used for biocontrol or biopreservation in the food and feed chain. Antonie Van Leeuwenhoek 2011, 99, 113-119. [CrossRef] [PubMed]

18. Oro, L.; Feliziani, E.; Ciani, M. Biocontrol of postharvest brown rot of sweet cherries and population dynamic of Saccharomyces cerevisiae Disva599, Metschnikowia pulcherrima Disva267 and Wickerhamomyces anomalus Disva2 strains. Postharvest Biol. Technol. 2014, 96, 64-68. [CrossRef]

19. Parafati, L.; Vitale, A.; Restuccia, C.; Circilleri, G. Biocontrol ability and action mechanism of food-isolated yeast strains against Botrytis cinerea causing post-harvest bunch rot of table grape. Food Microbiol. 2015, 47, 85-92. [CrossRef] [PubMed]

20. Cordero-Bueso, G.; Mangieri, N.; Maghradze, D.; Foschino, R.; Valdetara, F.; Cantoral, J.M.; Vigentini, I. Wild grape-associated yeasts as promising agents against Vitis vinifera fungal pathogens. Front. Microbiol. 2017, 8. [CrossRef] [PubMed]

21. Grzegorczyk, M.; Żarowska, B.; Restuccia, C.; Cirvilleri, G. Postharvest biocontrol ability of killer yeasts against Monilinia fructigena and Monilinia fructicola on stone fruit. Food Microbiol. 2017, 61, 93-101. [CrossRef] [PubMed] 
22. Bisson, L.F.; Joseph, C.M.L.; Domizio, P. Yeasts. In Biology of Microorganisms on Grapes, in Must and in Wine; König, H., Unden, F., Fröhlich, J., Eds.; Springer International Publishing AG: Basel, Switzerland, 2017; pp. 65-101.

23. São-José, C.; Santos, M.A.; Schmitt, M.J. Viruses of wine-associated yeasts and bacteria. In Biology of Microorganisms on Grapes, in Must and in Wine; König, H., Unden, G., Fröhlich, J., Eds.; Springer International Publishing AG: Basel, Switzerland, 2017; pp. 133-153.

24. Hua, S.S.; Beck, J.J.; Sarreal, S.B.; Gee, W. The major volatile compound 2-phenylethanol from the biocontrol yeast, Pichia anomala, inhibits growth and expression of aflatoxin biosynthetic genes of Aspergillus flavus. Mycotoxin Res. 2014, 30, 71-78. [CrossRef] [PubMed]

25. Jijakli, M.H. Pichia anomala in biocontrol for apples: 20 years of fundamental research and practical applications. Antonie Van Leeuwenhoek 2011, 99, 93-105.

26. Prillinger, H.; Messner, R.; König, H.; Bauer, R.; Lopandic, K.; Molnar, O.; Dangel, P.; Weigang, F.; Kiristis, T.; Nakase, T.; et al. Yeasts associated with termites: A phenotypic and genotypic characterization and use of coevolution for dating evolutionary radiations in Asco- and Basidiomycetes. Syst. Appl. Microbiol. 1996, 19, 265-283. [CrossRef]

27. Bäumlisberger, M.; Moellecken, U.; König, H.; Claus, H. The potential of the yeast Debaryomyces hansenii H525 to degrade biogenic amines in food. Microorganisms 2015, 3, 839-850. [CrossRef] [PubMed]

28. Radler, F.; Pfeiffer, P.; Dennert, M. Killer toxins in new isolates of the yeasts Hanseniaspora uvarum and Pichia kluyveri. FEMS Microbiol. Lett. 1985, 29, 269-272.

29. Zorg, J.; Kilian, S.; Radler, F. Killer toxin producing strains of the yeasts Hanseniaspora uvarum and Pichia kluyveri. Arch. Microbiol. 1988, 149, 261-267. [CrossRef]

30. Schlander, M.; Distler, U.; Tenzer, S.; Thines, E.; Claus, H. Purification and properties of yeast proteases secreted by Wickerhamomyces anomalus 227 and Metschnikowia pulcherrima 446 during growth in a white grape juice. Fermentation 2017, 3, 2. [CrossRef]

31. Sabel, A.; Martens, S.; Petri, A.; König, H.; Claus, H. Wickerhamomyces anomalus AS1: A new strain with potential to improve wine aroma. Ann. Microbiol. 2014, 64, 483-491. [CrossRef]

32. Schwentke, J.; Sabel, A.; Petri, A.; König, H.; Claus, H. The wine yeast Wickerhamomyces anomalus AS1 secretes a multifunctional exo-\$-1,3 glucanse with implications for winemaking. Yeast 2014, 31, 349-359. [CrossRef] [PubMed]

33. Pfannebecker, J.; Schiffer-Hetz, C.; Fröhlich, J.; Becker, B. Culture medium optimization for osmotolerant yeasts by use of a papallel fermenter system and rapid microbiological testing. J. Microbiol. Methods 2016, 130, 14-22. [CrossRef] [PubMed]

34. Molnar, O.; Schatzmayr, G.; Fuchs, E.; Prillinger, H. Trichosporon mycotoxinivorans sp. nov., a new yeast species useful in biological detoxification of various mycotoxins. Syst. Appl. Microbiol. 2004, 27, 661-671. [CrossRef] [PubMed]

35. Handel, S.; Wang, T.; Yurkov, A.M.; König, H. Sugiyamaella mastotermitis sp. nov. and Papiliotrema odontotermitis f.a., sp. nov. from the gut of the temites Mastotermes darwiniensis and Odontotermes obesus. Int. J. Syst. Evol. Microbiol. 2016, 66, 4600-4608. [PubMed]

36. Charoenchai, C.; Fleet, F.H.; Henschke, P.A.; Todd, B.E.N. Screening of non-Saccharomyces wine yeasts for the presence of extracellular hydrolytic enzymes. Aust. J. Grape Wine Res. 1997, 3, 2-8. [CrossRef]

37. Fernández, M.; Úbeda, J.F.; Briones, A.I. Typing of non-Saccharomyces yeasts with enzymatic activities of interest in wine-making. Int. J. Food Microbiol. 2000, 59, 29-36. [CrossRef]

38. Strauss, M.L.A.; Jolly, N.P.; Lambrechts, M.G.; van Rensburg, P. Screening for the production of extracellular hydrolytic enzymes by non-Saccharomyces wine yeasts. J. Appl. Microbiol. 2001, 91, 182-190. [CrossRef] [PubMed]

39. Raspor, P.; Miklič-Milek, D.; Avbely, M.; Čadež, N. Biocontrol of grey mould disease on grape caused by Botrytis cinerea with autochthonous wine yeasts. Food Technol. Biotechnol. 2010, 48, 336-343.

40. Sipiczki, M. Metschnikowia strains isolated from botrytized grapes antagonize fungal and bacterial growth by iron depletion. Appl. Environ. Microbiol. 2006, 72, 6716-6724. [CrossRef] [PubMed]

41. Saravanakumar, D.; Ciavorella, A.; Spadaro, D.; Garibaldi, A.; Gullino, M.L. Metschnikowia pulcherrima strain MACH1 outcompetes Botrytis cinerea, Alternaria alternata and Penicillium expansum in apples through iron depletion. Postharvest Biol. Technol. 2008, 49, 121-128. [CrossRef] 
42. Chan, Z.; Tian, S. Interaction of antagonistic yeasts against postharvest pathogens of apple fruit and possible mode of action. Postharvest Biol. Technol. 2005, 36, 215-223. [CrossRef]

43. Zhang, D.; Spadaro, D.; Garibaldi, A.; Gullino, M.L. Efficacy of the antagonist Aureobasidium pullulans PL5 against postharvest pathogens of peach, apple and plum and its modes of action. Biol. Control 2010, 54, 172-180. [CrossRef]

44. Walker, A.S. Diversity within and between species of Botrytis. In Botrytis-The Fungus, the Pathogen and Its Management in Agricultural Systems; Fillinger, S., Elad, Y., Eds.; Springer International Publishing: Basel, Switzerland, 2016; pp. 91-125.

45. Sláviková, E.; Vadkertiková, R.; Vránová, D. Yeasts colonizing the leaf surfaces. J. Basic Microbiol. 2007, 47, 344-350. [CrossRef] [PubMed]

46. Janisiewicz, W.J.; Jurick, W.M.; Peter, K.A.; Kurtzman, C.; Buyer, J. Yeast associated with plum and their potential for controlling brown rot after harvest. Yeast 2014, 31, 207-218. [CrossRef] [PubMed]

47. Molnárova, J.; Vadkertiová, R.; Stratilová, E. Extracellular enzymatic activities and physiological profiles of yeasts colonizing fruit trees. J. Basic Microbiol. 2014, 54, S74-S84. [CrossRef] [PubMed]

48. Varela, C.; Borneman, A.R. Yeasts found in vineyards and wineries. Yeast 2017, 34, 111-128. [CrossRef] [PubMed]

49. Spadaro, D.; Vola, R.; Piano, S.; Gullino, M.L. Mechanisms of action and efficacy of four isolates of the yeast Metschnikowia pulcherrima active against postharvest pathogens on apples. Postharvest Biol. Technol. 2002, 24, 123-134. [CrossRef]

50. Oro, L.; Feliziani, E.; Ciani, M.; Romanazzi, G.; Comitini, F. Volatile organic compounds from Wickerhamomyces anomalus, Metschnikowia pulcherrima and Saccharomyces cerevisiae inhibit growth of decay causing fungi and control postharvest diseases of strawberries. Int. J. Food Microbiol. 2018, 265, 18-22. [CrossRef] [PubMed]

51. Tian, Y.Q.; Li, W.; Linag, Z.T.; Jing, M.M.; Shao, Y.Z. The preservation effect of Metschnikowia pulcherrima yeast on anthracnose of postharvest mango fruits and the possible mechanism. Food Sci. Biotechnol. 2018, 27, 95-105. [CrossRef]

52. Sisti, M.; Savani, V. Antifungal properties of the human Metschnikowia strain IHEM 25107. Folia Microbiol. 2013. [CrossRef] [PubMed]

53. Hershkovitz, V.; Sela, N.; Taha-Salaime, L.; Liu, J.; Rafael, G.; Kessler, C.; Aly, R.; Levy, M.; Wisniewski, M.; Droby, S. De-novo assembly and characterization of the transcriptome of Metschnikowia fructicola reveals differences in gene expression following interaction with Penicillium digitatum and grapefruit peel. MMC Genom. 2013, 14, 168. [CrossRef] [PubMed]

54. Spadaro, D.; Lorè, A.; Garibaldi, A.; Gullino, M.L. A new strain of Metschnikowia fructicola for postharvest control of Penicillium expansum and patulin accumulation on four cultivars of apple. Postharvest Biol. Technol. 2013, 75, 1-8. [CrossRef]

55. Kurtzman, C.P.; Droby, S. Metschnikowia fructicola, a new ascosporic yeast with potential for biocontrol of postharvest fruit rots. Syst. Appl. Microbiol. 2001, 24, 395-399. [CrossRef] [PubMed]

56. Lachance, M.A. Metschnikowia: Half tetrads, a regicide and the fountain of youth. Yeast 2016, 33, 563-574. [CrossRef] [PubMed]

57. Piombo, E.; Sela, N.; Wisniewski, M.; Hoffmann, M.; Gullino, M.L.; Allard, M.W.; Levin, E.; Spadaro, D.; Droby, S. Genome sequence, assembly and characterization of two Metschnikowia fructicola strains used as biocontrol agents of postharvest diseases. Front. Microbiol. 2018, 9, 593. [CrossRef] [PubMed]

58. Türkel, S.; Ener, B. Isolation and characterization of new Metschnikowia pulcherrima strains as producers of the antimicrobial pigment pulcherrimin. Z. Naturforsch. 2009, 64, 405-410. [CrossRef]

59. Banani, H.; Spadaro, D.; Zhang, D.; Matic, S.; Garibaldi, A.; Gullino, M.L. Postharvest application of a novel chitinase from Metschnikowia fructicola and overexpressed in Pichia pastoris to control brown rot of peaches. Int. J. Food Microbiol. 2015, 199, 54-61. [CrossRef] [PubMed]

60. Saravanakumar, D.; Spadaro, D.; Garibaldi, A.; Gullino, M.L. Detection of enzymatic activity and partial sequence of a chitinase in Metschnikowia pulcherrima strain MACH1 used as postharvest biocontrol agent. Eur. J. Plant Pathol. 2009, 123, 183-193. [CrossRef]

61. Grevesse, C.; Lepoivre, P.; Jijakli, M.H. Characterization of the exoglucanase-encoding gene PaEXG2 and study of its role in the biocontrol activity of Pichia anomala strain K. Phytopathology 2003, 93, 1145-1152. [CrossRef] [PubMed] 
62. Friel, D.; Gomez Pessoa, N.M.; Vandenbol, M.; Jijakli, M.H. Separate and combined disruptions of two exo-ß-1,3-glucanase genes decrease the efficiency of Pichia anomala (Strain K) biocontrol against Botrytis cinerea on apple. Mol. Plant Microbe Interact. 2007, 20, 371-379. [CrossRef] [PubMed]

63. Zhang, D.; Spadaro, D.; Valente, S.; Garibaldi, A.; Gullino, M.L. Cloning, characterization and expression of an exo-1,3-ßs-glucanase gene from the antagonistic yeast, Pichia guilliermondii strain M8 against grey mold on apples. Biol. Control 2011, 59, 284-293. [CrossRef]

64. Zhang, D.; Spadaro, D.; Valente, S.; Garibaldi, A.; Gullino, M.L. Cloning, characterization, expression and antifungal activity of an alkaline serine protease of Aureobasidium pullulans PL5 involved in the biological control of pathogens. J. Food Microbiol. 2012, 153, 453-464. [CrossRef] [PubMed]

65. Salazar, O.; Asenjo, J.A. Enzymatic lysis of microbial cells. Biotechnol. Lett. 2007, 29, 985-994. [CrossRef] [PubMed]

66. König, H.; Li, L.; Fröhlich, J. The cellulolytic system of the termite gut. Appl. Microbiol. Biotechnol. 2013, 97, 7943-7962. [CrossRef] [PubMed]

67. Khalel, A.S.; Khaled, J.M.; Kandeal, S.A. Enzymatic activity and some molecular properties of Trichosporon mycotoxinovorans yeast and their effect on liver function in mice. Afr. J. Microbiol. Res. 2012, 6, 2567-2573.

68. Bourdichon, F.; Casarogola, S.; Farrokh, C.; Frisvad, J.C.; Gerds, M.L.; Hammes, W.P.; Harnett, J.; Huys, G.; Laulund, S.; Ouwehand, A.; et al. Food fermentations: Microorganisms with technological beneficial use. Int. J. Food Microbiol. 2012, 154, 87-97. [CrossRef] [PubMed]

(C) 2018 by the authors. Licensee MDPI, Basel, Switzerland. This article is an open access article distributed under the terms and conditions of the Creative Commons Attribution (CC BY) license (http:/ / creativecommons.org/licenses/by/4.0/). 